\title{
Krónikus beteg munkavállalók támogatása, munkahelyi betegségmegelözés: Az Európai Unió Chrodis Plus közös fellépésének munkahelyek számára kínált jógyakorlatai
}

\author{
Support to employees with chronic conditions, disease prevention at the workplace: \\ Good practices of the European Union Joint Action Chrodis Plus to employers \\ Dr. Kovács Réka, Aszalós Zoltán, Dr. Cserháti Zoltán, Dr. Palicz Tamás \\ Semmelweis Egyetem Egészségügyi Menedzserképző Központ, Budapest
}

2018-ban az európai munkavállalók több mint negyede szenvedett tartós egészségügyi problémától. A krónikus betegek számának az elmúlt évtizedekben tapasztalt drasztikus emelkedése jelentős társadalmi és gazdasági következményekkel jár. $A$ tanulmány célja, hogy részletesen bemutassa az Európai Unió 3 . Egészségügyi Programja által támogatott CHRODIS Plus Közös Fellépés (chrodis.eu) krónikus betegségek munkahelyi megelőzésével és kezelésével foglalkozó jelentését, az ún. Eszközkészletet, amely a krónikus betegséggel küzdő munkavállalók munkaképességének javítását, munkahelyi integrációját segítő, menedzsereknek szánt Képzési Módszertanból, illetve egy, a munkavállalók jóllétét, egészségét és munkavégzését támogató Eszköztárból áll, mely hét témakörben kínál konkrét javaslatokat az egészségtudatos munkahelyek támogatására.

In 2018, more than every fourth European worker suffered from a chronic condition, and the drastic increase in the number of people with chronic diseases in recent decades has significant social and economic consequences. The aim of the study is to evaluate, analyse and disseminate the output report on the prevention and treatment of chronic diseases in the workplace, the so-called "Workbox" of the CHRODIS Plus Joint Action (chrodis.eu), which was financed by the European Union's Public Health Programme (2014-2020). The CHRODIS Plus Workbox contains a Training Tool a methodology for managers to improve the inclusiveness of their workplace and the ability to improve the work of their employees with chronic conditions - and a Toolkit aiming to support the well-being, health and work of employees in seven fields by offering concrete proposals to support the establishment of health-conscious workplaces.

\section{BEVEZETÉS}

2018-ban Európa országaiban a munkavállalók több mint negyede szenvedett tartós egészségügyi problémától, és a népesség még nagyobb aránya esetében volt valószínűsíthető, hogy ilyen problémák a jövőben kialakulhatnak [1]. Az egy vagy több krónikus betegséggel küzdők számának az elmúlt évtizedekben történt drasztikus emelkedése jelentős társadalmi és gazdasági következményekkel jár [2]. Az Országos Egészségfejlesztési Intézet 2012-es tanulmánya szerint Magyarországon például 2010-ben a teljes halálozás egyhatoda volt köthető a dohányzáshoz, mint a krónikus betegségek egyik fontos rizikófaktorához. A gazdasági következményeket pedig jól illusztrálja, hogy a magyar lakosság dohányzás miatt fellépő közvetlen és közvetett kiadásai 2010-ben meghaladták a 441 milliárd forintot, ezzel szemben a dohányzásnak tulajdonítható állami bevételek mindössze a 360 milliárd forintot érték csak el [3]. Az alkoholfogyasztás hasonlóan nagy népegészségügyi terhet jelent. Hazánkban a túlzott alkoholfogyasztás következtében elveszített életévek száma nemzetközi összehasonlításban a legmagasabbak közt található [4]. A kedvezőtlen népegészségügyi mutatók a magyar döntéshozókat is a 2010-es évektől a népegészségügyi termékadó, illetve a dohányzás visszaszorítását célzó számos intézkedés bevezetésére sarkallták [3,5]. Az egyén szintjén vizsgálva a jelenséget, a krónikus betegséggel élők elhelyezkedési, továbbképzési lehetőségei korlátozottabbak, sok esetben nehezebb számukra az előmenetel, alacsonyabb a kereset, illetve gyakran belekényszerülnek a korai nyugdíjazásba. Sokszor komoly, tapasztalt szakembereket veszít el a munkaerőpiac krónikus betegség(ek) miatt, leginkább azért, mert a munkaadók gyakran nem tudják, hogy a krónikus betegséggel küzdők milyen eséllyel tudják folytatni a munkát, vagy milyen módon, eszközökkel lehetne őket ebben támogatni [6,7].

Erre a kihívásra válaszul készült el az Európai Unió 3. Egészségügyi Programja által támogatott projekt, a CHRODIS Plus közös fellépés [8], mely számos stratégiai javaslatot, ajánlást eredményezett $[9,10]$. A projekt keretében egy ún. Eszközkészletet [11] dolgozott ki az egyik munkacsoport, melynek célja, hogy támogassa az EU tagállamaiban működő munkahelyeket az egészséges és biztonságos munkakörülmények megteremtésében, segítse azokat a krónikus betegségek megelőzésében, valamint hozzájáruljon a krónikus betegséggel élők további foglalkoztatásához. Számos előnnyel jár ugyanis az érintett munkavállalókon túl a munkahelyek és az egész társadalom számára, ha a munkáltatók odafigyelnek a krónikus betegségek megelőzésére, illetve az érintettek megfelelő bevonására. Nemcsak a munkavállalók egészségi állapota, munkahelyi részvétele, elégedettsége, produktivitása javul, hanem a vállalatok hiányzásból, illetve 
munkaerő-cserélődésből fakadó költségei is csökkennek, termelékenységük és versenyképességük nő, a felhalmozódott tapasztalat pedig továbbra is rendelkezésükre áll. A projekt 3 éves időtartama alatt 21 európai ország 42 partner szervezete - köztük a Semmelweis Egyetem Egészségügyi Menedzserképző Központja, mint a komplex szakmai tartalomfejlesztéssel járó projektkommunikáció irányítója - működött együtt azon gyakorlatok kifejlesztésében, amelyek támogatják a krónikus betegséggel élők munkában maradását.

A Chrodis Plus Eszközkészlet a krónikus betegséggel küzdő munkavállalók munkaképességének javítását, munkahelyi integrációját segítő, menedzsereknek szánt Képzési Módszertanból [12], illetve egy, a munkavállalók jóllétét, egészségét és munkavégzését támogató Eszköztárból [13] áll. Jelen publikáció az Eszközkészlet főbb javaslatainak rövid bemutatását célozza.

\section{MÓDSZERTAN}

A bemutatandó javaslatokat tartalmazó két dokumentum szerint a szerzők nemzetközi tanulmányok és projektek eredményeire támaszkodtak (pl. EU Pathway projekt - www.pathwaysproject.eu), illetve nemzetközi szakértők - így szakpolitikusok, népegészségügyi szakemberek, háziorvosok, kutatóorvosok, betegszervezetek és egyéb nemzetközi szervezetek - támogatására, szakértői hozzájárulására is alapozhattak. A munkahelyek számára javasolt ötletek összegyűjtésében a szakirodalom elemzésén túl ágazati vezetőkkel, alkalmazottakkal, foglalkozás-egészségügyi szakemberekkel folytatott interjúk is segítették a projekt szakértőit abban, hogy azonosítsanak olyan, bizonyítottan hatékony és megvalósítható módszereket, amelyek elősegíthetik a munkavállalók egészségének, jóllétének és munkahelyi részvételének fejlesztését, valamint a krónikus betegségek megelőzését. Jelen cikk az eredmények leíró jellegű bemutatására vállalkozik.

\section{AZ ESZKÖZKÉSZLET KÉPZÉSI MÓDSZERTAN ELEME}

A Képzési Módszertan a munkahelyek vezetői és humán erőforrás-menedzserei számára készült annak érdekében, hogy növelje tudatosságukat a krónikus egészségügyi problémákkal élő vagy azoknak kitett munkavállalókra vonatkozóan, segítse a munkaképesség mérését, illetve az érintett munkavállalók integrációját a számukra megfelelő munkakörnyezet biztosításával. A Képzési Módszertan szerzői hangsúlyozzák, hogy a vállalat fő értéke a munkavállaló, és a krónikus betegséggel élő alkalmazottak esetében kevés az elérhető olyan információ, amely terhelhetőségüket, munkaképességüket mérni tudná, így gyakran terjednek téves információk egészségi állapotukra vonatkozóan, ami sokszor megbélyegzésükhöz is vezet. Pedig a jól menedzselt krónikus betegséggel élők támogató munkakörnyezet esetén ugyanúgy helyt tudnak állni, mint egészséges társaik, illetve egy betegség utáni rehabilitációjuk, és munkahelyi visszatérésük is könnyebbé válhat megfelelő módszerek alkalmazásával. Jelentős előnyökkel járhat nemcsak az érintett munkavállalók, de a vállalatok és egyúttal az egész társadalom számára is, ha a munkaerőpiac megfelelően képes kezelni a komplex és krónikus betegséggel járó állapotokat, hiszen egy széleskörű tudással és tapasztalattal rendelkező, krónikus beteg munkavállaló visszatérése a vállalathoz növelheti a cég és a nemzetgazdaság produktivitását egyaránt. A Képzési Módszertan nem titkolt további célja egyfajta inspiráló párbeszéd, vita beindítása az európai munkahelyeken, a foglalkoztatottság, a krónikus betegségek, az integráció és a munkaképesség témaköreiben.

\section{Munkahelyi integráció, inkluzivitás}

A Képzési Módszertan segítséget kíván nyújtani a munkahelyeknek abban, hogy az integráció, sokféleség, befogadás (átfogó néven inkluzivitás) szintjét mérni, értékelni tudják. A Módszertan olyan javaslatokat fogalmaz meg, amelyek alapján a cégek eleget tudnak tenni a különböző egészségügyi problémákkal élők szükségleteinek, segíteni tudják az együttmúködést a cég kulturális környezetétől eltérő egyénekkel, csoportokkal, szervezetekkel. Az inkluzivitás mérésére a Képzési Módszertan nemzetközi referenciákra támaszkodva [14-16] egy önértékelési eszközt, ún. ellenőrző listát is kínál a munkaadóknak, az értékelést segítő szempontokkal együtt.

Az ellenőrző lista által lefedett négy területen - munkakörnyezet, elvárható infrastruktúra, vezetői szektor, csapatmunka - 10-10 kérdést tesz fel, amelyekre attól függően, hogy jellemző-e a cégre vagy nem, a válaszadónak az IGEN vagy a NEM választ kell megadnia. Fontos, hogy ezt vezetők és alkalmazottak is kitöltsék, illetve több munkahelyi terület munkatársai is, hiszen a vélemények összehasonlítása segíthet a megfelelő intézkedések meghozatalában. Az ellenőrzőlistán szereplő válaszok elemzése lehetővé teszi, hogy átfogó képet kapjunk a cég erősségeiről és gyengeségeiről, ahol az alacsony pontszámot elért témakörök a beavatkozásra szoruló területeket jelölik. Az ellenőrző lista tehát egy jól használható, kézzelfogható önértékelési eszköz, mely segít a szervezeti fejlesztési irányok kijelölésében.

\section{A munkaképesség mérése}

A Képzési Módszertan által ajánlott másik mérési eszköz a munkaképességi index (WAI - work ability index [17]). A munkaképességi index egy önértékelő eszköz, amely a munkakörnyezet hatásait is figyelembe véve méri az alkalmazottak munkabírását. A munkaképesség megállapításakor azt vizsgálja, hogy egy alkalmazott képes-e, illetve mennyiben képes a jelenlegi és jövőbeli munkaköri elvárásoknak és a munkakörnyezetnek megfelelni fizikai és mentális állapotának fényében. Az egészségi állapot és a funkcionális képességek felmérése képezi a munkaképesség mérésének alapját, ugyanakkor a munkaképességet a szakmai ismeretek és kompetenciák, az értékek, attitűdök, a motiváció, a munka jellege és a munkakörnyezet is meghatározzák, ezért ezekre is figyelemmel kell lenni. A fizikailag megterhelő, nehezített környezetben történő, vagy nehezen ellenőrizhető és nehezen kivitelezhető feladatokkal járó munkakörök mind csökkentik a munkaképességet. A Képzési Módszertan által ajánlott munkaképességi index (WAI) az 1980as években a Finn Foglalkozás-egészségügyi Intézet által kidol- 
gozott kérdőív. Létrehozása során az alapvető tudományos kérdés az volt, hogy az alkalmazottak és a munkáltatók mennyi ideig képesek dolgozni, és hogy a munkaképesség milyen mértékben függ a munka tartalmától és a munkaköri igényektől. A munkaképesség fogalmát később számos más európai és ázsiai országban is elfogadták [18]. A munkaképességi index 7 részből tevődik össze, legmagasabb értéke 49 pont lehet, a legrosszabb pedig 7 pont. Az eredmények értékelése kapcsán fontos megjegyezni, hogy az alacsony értékek, a „rossz munkaképesség” nem az egyéni képességek hiányát, hanem azt jelenti, hogy a munka által támasztott követelmények és a munkavállaló képességei nem állnak összhangban egymással. A munkavállalók hatékonyságának növelése vagy a munka termelékenységének javítása érdekében akkor lehet konkrét intézkedéseket megfogalmazni, ha ismertek a munkaképességet egyéni vagy a környezeti szinten meghatározó tényezők.

\section{A krónikus betegséggel élő munkavállalók támogatása}

A Képzési Módszertan javasolja, hogy miután egy munkahely a fentiekben bemutatott eszközökkel azonosította erösségeit és gyengeségeit, cselekvési tervet dolgozzon ki az összes munkavállaló - de különösen a krónikus betegségekben szenvedők - munkahelyi integrációjának és jóllétének támogatására, megerősítésére. Ennek a cselekvési tervnek a munkában tartást, illetve a (pl. a betegséget követően) munkába való visszatérést egyaránt segítenie kell. A cselekvési terv kapcsán a következő tippeket adja a Képzési Módszertan:

- az ésszerū, a munkavállalóktól elvárható alkalmazkodás érdekében reális és mérhető lépések meghatározása, a munkavállalókkal együttműködésben (pl. a munkakörnyezeten, közösségi tereken végzett változtatások);

- a munkaköri leírások áttekintése, a munkavállalókra vonatkozó elvárások kiigazítása, pontosítása;

- az alkalmazottakkal az őket segítő változtatások egyeztetése, hiszen jobban tudnak igazodni azokhoz a változtatásokhoz, amelyeket maguk javasoltak;

- a változtatások megvalósításához szükséges erőforrások, az erőforrásokhoz való hozzáférés lehetőségeinek felmérése (részmunkaidő, otthoni munkavégzés, rugalmas munkaidő, munkakörváltoztatás stb.);

- stratégia kidolgozása a krónikus beteg munkavállalók bevonására, a velük való rendszeres kapcsolattartásra (pl. otthoni munkavégzés esetén konferenciahívás vagy video chat, közösségi eseményekbe bevonás);

- foglalkozás-egészségügyi szakértők bevonása a munka (-hely) és egészség közti kapcsolat figyelemmel kísérésére;

- nyílt kommunikáció alkalmazása krónikus megbetegedések témában (pl. online kurzusok vagy szóróanyagok biztosításával, illetve külsős szakértők bevonásával) - az egészséges kollégák körében is - a krónikus betegségekkel kapcsolatos, tudatlanságból eredő stigmatizálás és diszkrimináció megszüntetése érdekében.

\section{Munkában tartás segítése}

A krónikus betegséggel élő munkavállalók munkavégzésük fenntartása érdekében folyamatos támogatásra szorulnak.
Figyelemmel kell kísérni a már bevezetett módosításokat, hogy működnek-e, vagy újragondolásukra van szükség. Tekintettel kell lenni a krónikus betegek állapotának esetleges súlyosbodására, és fenn kell tartani, illetve javítani kell a betegek és egészségesek közötti szervezeti együttműködést. A dolgozók számára javasolt tájékoztató anyagokat eljuttatn különböző módokon (e-mail, hírlevél, közös helyiségek képernyői), illetve az intraneten az összes alkalmazott számára hozzáférhető képzési program indítható a befogadó munkakörnyezet fejlesztése érdekében. Ez utóbbi tartalmi elemeire vonatkozóan konkrét javaslatokkal is él a Képzési Módszertan, mint pl. tájékoztató lapok az egyes betegségekről; iránymutatások a krónikus betegségek pszichológiai, jogi és orvosi vetületeiről; webináriumok a befogadó munkakörnyezet előnyeiről, a kollegiális kapcsolatokról vagy a munkahelyen eszközölhető ésszerű változtatási lehetőségekről; videók a betegségekke kapcsolatos sztereotípiákról és következményeikről; online kurzusok a vállalati konfliktuskezelésröl, kommunikációs technikákról, a csoportdinamikáról és a sokféleség kezeléséről.

\section{Munkába visszatérést támogató programok}

Fontos, hogy a munkáltatók rendelkezzenek munkába visszatérést segítő irányelvekkel, programokkal, és ezeket ne csak leírják, hanem következetesen végre is hajtsák. A vezetők és döntéshozók képzése is javasolt, hogy megismerjék a munkavállalókra vonatkozó szabályokat és tudják azokat alkalmazni, és a munkavállalókkal megismertetni is. A Képzési Módszertan konkrét javaslatot is tesz online, illetve személyes képzési tartalmakra, amelyeken igény szerint vehetnének részt a menedzserek és a HR munkatársak. Ilyen online képzések lehetnek webináriumok például, ahol bemutatják a munkába visszatérést támogató megoldásokat, az ilyen programok kidolgozását segítő útmutatókat, vagy a krónikus betegségből visszatérők interjúztatására, illetve későbbi utókövetésére vonatkozó lehetőségeket. A személyes tréning pedig tartalmazhatja többek között a következő modulokat: feladatok és munkaköri tevékenységek meghatározása a visszatérést segítő programon belül, a visszatérést segítő eszközök fejlesztése, a munkába való visszatérés jó gyakorlatának meghonosítása, illetve a supervisorok és menedzserek szerepe a munkába visszatérés folyamatában. A képzések hatékonyságának monitorozása érdekében célszerű éves felméréseket végezni a menedzserek között, hogy mennyire tartják eredményesnek a képzést, illetve vane bármilyen javaslatuk a témák bővítésére vonatkozóan.

\section{A krónikus beteg munkavállalókat támogató munkahelyi környezet fejlesztése}

A munkavállalók bevonásával érdemes végiggondolni azon ésszerű változtatási, fejlesztési lehetőségeket, amelyek a hátrányosabb helyzetű, krónikus beteg vagy más speciális szükségletű munkavállalók fejlődését biztosítják, illetve hozzásegítik őket feladataik megfelelő módon történő elvégzéséhez. Ezen módosításoknak egyéb, az egész munkahely szellemiségét is érintő hatásai lehetnek, mint például a krónikus betegségekről való gondolkodásmód pozitív irányba 
történő változása, a munkahelyen belüli toleranciaszint növekedése. A Képzési Módszertan segít néhány ötlettel, úgy, mint rugalmas napi/heti beosztás, részmunkaidő, munkaeszközök beszerzése vagy cseréje (pl. telekommunikációs eszközök hallássérültek számára, nyomógombos telefonok, speciális szoftverek, állítható magasságú munkaasztal stb.), illetve a munkahely teljes akadálymentesítése.

A krónikus beteg munkavállalók integrációját elősegíteni hivatott Képzési Módszertan végül egy nagyon hasznos függelékben mutatja be a munkahelyen előforduló leggyakoribb krónikus betegségeket (idegrendszeri, mozgásszervi, szívés érrendszeri, légzőszervi, anyagcsere-rendellenességek), amely a rövid bemutatáson, esetleíráson és kezelési lehetőségeken túl kitér a betegségek foglalkoztathatóságra gyakorolt hatásaira, illetve az adott betegséggel küzdő munkavállaló integrációját segítő tanácsokra.

\section{AZ ESZKÖZKÉSZLET ESZKÖZTÁR ELEME}

A munkahelyek támogatásának céljából konkrét stratégiákat, illetve kézzelfogható eszközöket javasol az Eszközkészlet másik eleme, az Eszköztár, a munkavállalók egészségének, jóllétének és munkahelyi részvételének fejlesztése céljából, a dolgozók munkaképességétől és egészségi állapotától függetlenül. Az Eszköztár által kínált jó gyakorlatok és megoldások elősegítik továbbá az olyan krónikus betegségek megelőzését, mint a szív- és érrendszeri betegségek, a 2-es típusú cukorbetegség, mozgásszervi betegségek, depresszió és különböző tüdőbetegségek.

Az Eszköztár hét területre vonatkozóan - táplálkozás, fizikai aktivitás, ergonómia, mentális egészség és jóllét, munka utáni regenerálódás, közösségi szellem és légkör, a dohányzásról való leszokás és a túlzott alkoholfogyasztás csökkentése - tartalmaz módszereket, és ezeken a területeken a következő négy megközelítés szerint csoportosítja javaslatait: a tudás és a készségek fejlesztése, támogató munkakörnyezet megteremtése, a jóllét előmozdítását célzó alapelvek és ösztönzők. Az ajánlott megoldások jelentős része könnyen megvalósítható, ami azt jelenti, hogy alacsony személyi, anyagi, vagy időráfordítást igényel. Az ilyen javaslatokat külön piktogram jelöli. Az Eszköztárat egyaránt lehet használni ellenőrzőlistaként (mellékletben kínál egy állapotfelmérő listát, mely meghatározhatja a fejlesztések kiindulópontját), és ötlettárként is, hiszen 127 konkrét javaslatot mutat be. Ezen javaslatokból mutatunk be a következőkben témánként néhányat, a teljesség igénye nélkül.

\section{Táplálkozás}

A munkahelyeknek kiváló lehetőségeik vannak arra, hogy támogassák az alkalmazottakat az egészséges táplálkozási szokások elfogadásában és fenntartásában, hogy rendszeresen étkezzenek, és egészséges ételeket és italokat fogyasszanak. Fontos, hogy a munkaadók figyeljenek a munkahelyen kapható ételek és italok választékára a személyzeti éttermekben, kávézókban, árusító automatákban, rekreációs helyiségekben, illetve minden olyan esetben - például a meg- beszéléseken -, amikor ételeket és italokat szolgálnak fel.

Az Eszköztár azt is javasolja, hogy legyen lehetőség az alkalmazottak egészségi állapotának felmérésére, dietetikussal való konzultációra, illetve életmódot támogató vagy étkezési naplót kínáló digitális alkalmazás használatára. Kiemelten fontos, hogy a munkavállalók munkahelyi belső, vagy a munkahellyel szerződött külső étkezdékben tudjanak étkezni, ahol az egészséges ételek széles választékából tudnak választani. A szabadidős és közösségi helyiségekben ingyenesen lehessen fogyasztani egészséges harapnivalókat, friss gyümölcsöket, hiszen ez is nagy hatással van az étkezési szokások alakulására. Apró ötletekkel is jobban előtérbe helyezhetők az egészségesebb táplálékok, pl. külön edényeken, könnyen észrevehető (pl. szemmagasságban) és könynyen hozzáférhető módon elhelyezve, vagy növelve a gyümölcs és zöldség adagját, csomagolását és egységméretét, illetve csökkentve azokat a kevésbé egészséges alternatívák esetében.

\section{Fizikai aktivitás}

Megkérdőjelezhetetlen tudományos tény, hogy a fizikailag aktív életmód minden korosztályra, krónikus betegekre és egészségesekre egyaránt jó hatással bír. A munkáltatók szerepe viszont a fizikai aktivitás támogatásában jelenleg nem jelentős, pedig számos ösztönző eszközt alkalmazhatnának erre. A munkaadók például biztosíthatnak a munkavállalóik számára fizikaiállapot-felmérést, azt, hogy tevékenységnaplót, lépésszámlálót vagy aktivitáskövetőt használhassanak az önellenőrzéshez, illetve konzultáljanak egy gyógytornásszal. A munkáltatók megkönnyíthetik a kerékpáros munkába járást, ha megfelelő tárolókapacitást építtetnek, zuhanyzási lehetőséget biztosítanak, ezenfelül kialakíthatnak sportolásra alkalmas helyiségeket is. Szervezhetnek ún. aktív megbeszéléseket, ahol a kollégáknak van lehetőségük felállni, kicsit mozogni, vagy akár a munkahelyi számítógépre telepített automatikus tevékenységi emlékeztetőket is használhatnak, mely adott időközönként figyelmeztet egy rövid fizikai aktivitás szükségességére. Lecserélhetik a személyes nyomtatókat megosztott nyomtatókra; kihelyezhetnek könnyü edzőeszközöket (pl. gymstick, egyensúlyozó deszkák, gumiszalag, húzódzkodó rúd) olyan helyeken, ahol az alkalmazottak rövid időkre szünetet szoktak tartani (pl. nyomtatónál, kávéfőzőnél, mikrohullámú sütőnél), de olyan apró és olcsó trükköket is bevethetnek, mint a lépcsőhasználat ösztönzése plakátokon kihelyezett motivációs üzenetekkel, nyilak és lábnyomok elhelyezésével a padlón, vagy akár a liftek vagy a lift ajtajainak lelassításával.

\section{Ergonómia}

Az ergonómia arra a folyamatra utal, amikor a munkakörnyezetet, használati tárgyakat és rendszereket úgy tervezik és alakítják ki, hogy azok illeszkedjenek az azokat használó emberek igényeihez. Az ergonómia három fő területet foglal magában: fizikai (pl. munkavégzés közbeni testtartás, munkával kapcsolatos csont és izomrendszeri problémák), kognitív (pl. a munkafolyamatok megváltoztatása a mentális túlterhelés és stressz csökkentése érdekében) és szervezeti 
(pl. kommunikáció, csapatmunka, ütemezés). Az Eszköztár által tartalmazott ötletek itt is változatosak, magukban foglalják pl. a jó beltéri levegőminőség biztosítását $\mathrm{CO}_{2}$-mérőkkel, légtisztítókkal és porfogó szőnyegekkel; új, ergonomikus használati eszközök alkalmazását, mint például állítható magasságú székek, asztalok, ergonomikus székek, alkartámaszok, emelést segítő eszközök, ergonomikus billentyűzetek és számítógép egerek; vagy lecserélhetik a hagyományos íróasztalokat állítható magasságú íróasztalokra, hogy lehetővé tegyék munkavégzés közben a testhelyzet változtatását, például az állva történő irodai munkavégzést.

\section{Mentális egészség és jóllét}

A mentális egészség a jóllétnek (wellbeing) azon állapota, amelyben az egyén képes élni a benne rejlő képességekkel, meg tud küzdeni az élet mindennapos nehézségeivel, produktívan és eredményesen tud dolgozni, valamint hatékonyan hozzájárul a közösség életéhez. A munkahelyektől elvárható - és ehhez kitűnő lehetőségeik is vannak -, hogy támogassák a munkavállalóik mentális egészségét és segítsék őket abban, hogy a legjobb teljesítményüket tudják nyújtani azáltal, hogy csökkentik a munkával kapcsolatos stresszt. A munkavállalók ennek érdekében pszichológussal konzultálhatnak vagy stresszkezelési és megküzdési stratégiákat bemutató személyes vagy csoportos képzést (coachingot) kaphatnak. A munkáltatók a munkahelyi környezet átalakításával is segíthetik a jó mentális egészséget, például egy csendes szoba vagy helyiség kialakításával, ahol a laptopok és telefonok használata nem megengedett, illetve a munkakörnyezet változatossá tételével, például kávézók, kanapéval felszerelt társalgók, könyvtárak, és kellemes világítással felszerelt helyiségek kialakításával.

\section{Munka utáni regenerálódás}

Az egészséges, boldog és produktív élet előfeltétele a megfelelő egyensúly megtalálása a munka és a kikapcsolódás között. A munka utáni regenerálódás a munka során felhasznált fizikai, mentális és érzelmi erőforrások feltöltésének folyamatára utal. Az Eszköztár javaslatai között a munkaidőt, munkarendet érintők szerepelnek, mint pl. a rugalmas munkaidő, a távmunka, a munkarendek kiigazítása (például 9 órás munkanapok hétfőtől péntekig és csak 4 órás pénteken), illetve az élethelyzetre figyelemmel a személyes munkaterhelés kiigazítása, a csökkentett munkaidő lehetővé tétele. Valódi hozzáadott értéket jelenthet relaxációs lehetőség biztosítása, például, ha a heti munkaidőből 30 percet pihenésre fordíthatnak vagy akár kedvezményes árú masszázst vehetnek igénybe a munkahelyen. Rekreációs közösségi események szervezése, például közös ebéd, vagy kávézás munkaszünetben, munkaidő utáni közös sportprogramok, vetélkedők, kvízek szervezése szintén hasznos ötletek lehetnek.

\section{Közösségi szellem és légkör}

A pozitív munkahelyi légkör fejleszti a munkavállalók motivációját és ösztönzi őket jobb teljesítmény elérésérére. A támogató munkahelyi környezet és a munkatársak közötti jó kapcsolat elősegíti a mentális egészség megőrzését, egyúttal segít megküzdeni a munkahelyi és a személyes problémákkal is. Az Eszköztár javasolja a munkahetek nyitásaként és zárásaként közösségi összejövetelek szervezését; támogató, befogadó és elismerő munkahelyi légkör kialakítását, ennek támogatására interaktív munkahelyi workshopok, beszélgetések szervezését, ahol a vállalat vezetői és alkalmazottai végiggondolhatják, hogy hogyan tudják saját magatartásukkal ezeket az értékeket a munkahelyen megvalósítani. Javasolt továbbá a munkavállalók közül belső, munkahelyi „békéltetőket” képezni, rekreációs közösségi eseményeket szervezni, illetve a munkahelyi részlegek, vagy csoportok által választott szabadidős elfoglaltságokat (például sportprogram, vetélkedő, ebéd) anyagilag támogatni.

\section{A dohányzásról való leszokás és a túlzott alkoholfogyasztás csökkentése}

A munkahelynek fontos szerepe van a dohányzásról vagy túlzott alkoholfogyasztásról való leszokás támogatásában, melyek olyan krónikus betegségek kockázati tényezői, mint a szív- és érrendszeri betegségek, tüdőbetegségek és rosszindulatú daganatok. A munkáltatók felvállalhatják a munkavállalók képzését, tájékoztatását a dohányzás és az alkoholfogyasztás egészségkárosító hatásairól előadások, workshopok alkalmával, vagy információs standok, szórólapok és poszterek segítségével, illetve szükség szerint egyéni vagy csoportos tanácsadást tehetnek lehetővé. Jó megoldás a dohányzásról való leszokást célzó, munkahelyi kihívás/verseny indítása, vagy akár egy nikotinpótló terápián való részvétel anyagi támogatása is.

\section{KONKLÚZIÓ}

A Chrodis Plus projekt valódi értéke, hogy a szakirodalomban, korábbi projektekben, nemzetközi jelentésekben elérhető jó megoldások összegyűjtésén túl munkahelyi vezetők, alkalmazottak, foglalkozás-egészségügyi szakemberek bevonásával már bevált jó gyakorlatokat azonosítottak, és azokat könnyen felhasználható, jól érthető módon munkaerőpiaci szereplőkkel megosztották. Az elkészült dokumentumokat több nyelvre is lefordították, így szélesebb közönség számára tudnak hasznos ötleteket kínálni. A Semmelweis Egyetem Egészségügyi Menedzserképző Központja, a projekt kommunikációján keresztül a fö üzeneteket több magyarországi munkáltatóhoz is eljuttatta. Remélhetőleg a javasolt intézkedések alkalmazását mind több hazai és európai munkáltató gondolja majd fontosnak, és látja meg azok előnyét és jó hatását a munkavállalók, a vállalatok és az egész társadalom szempontjából egyaránt.

\section{Köszönetnyilvánítás}

A szerzők köszönetet mondanak a Chrodis Plus projekt valamennyi munkatársának és különösen a cikkben bemutatott Eszközkészletet összeállító munkacsoport vezetőinek: Matilde Leonardi, (Carlo Besta Neurológiai Intézet - Istituto Neurologico Carlo Besta, IRCCS Alapítvány, Milánó, Olaszország) és Jaana Lindström és Eeva Rantala, (Finn Egészségügyi és Népjóléti Intézet). 
IRODALOMJEGYZÉK

[1] OECD/European Union (2018), Health at a Glance: Europe 2018: State of Health in the EU Cycle, OECD Publishing, Paris/European Union, Brussels, https://doi.org/10.1787/health_glance_eur-2018-en

[2] Marc Suhrcke, Rachel A. Nugent, David Stuckler and Lorenzo Rocco. Chronic Disease: An Economic Perspective London: Oxford Health Alliance 2006. https://www.who.int/management/programme/ncd/Chro nic-disease-an-economic-perspective.pdf [megtekintve: 2022. 02. 10]

[3] Joó Tamás, Vokó Zoltán, Bodrogi József, Demjén Tibor, Szócska Miklós - Semmelweis Egyetem, Digitális Egészségtudományi Intézet, Semmelweis Egyetem, Egészségügyi Közszolgálati Kar, Egészségügyi Menedzserképző Központ, ELTE TáTK Közgazdaságtudományi Intézet, ELTE Társadalomtudományi Kar, OEFI: A dohányzás elleni küzdelem a 2010-2014 közötti időszakban. Interdiszciplináris Magyar Egészségügy. XVI. évfolyam. 2017. / 10. november-december https://www.imeonline.hu/article.php?article=2017._XVI. /10/a_dohanyzas_elleni_kuzdelem_a_2010_2014_kozo tti_idoszakban (megtekintve 2022. 02. 10.)

[4] Darvai László, Rihmer Zoltán, Balczár Lajos, Cserháti Zoltán, Túri Gergő, Bélteczki Zsuzsa, Kalabay László, Torzsa Péter: Az alkoholbetegség és a dohányzás interdiszciplináris vonatkozásai az alapellátás szemszögéből [Interdisciplinary aspects of alcoholism and smoking from the perspective of primary care]. LEGE ARTIS MEDICINAE 27 : 6-7 pp. 246-250. , 5 p. (2017)

[5] Joó Tamás, Palicz Tamás, Szócska Miklós - Semmelweis Egyetem, Egészségügyi Közszolgálati Kar, Egészségügyi Menedzserképző Központ, Semmelweis Egyetem, Digitális Egészségtudományi Intézet: A népegészségügyi termékadó dohánytermékekre való kiterjesztésének lehetősége. Interdiszciplináris Magyar Egészségügy. XVII. évfolyam. 2018. / 7. szeptember. 30-33 old. https://www.imeonline.hu/article.php?article= 2018._XVII./7/a_nepegeszsegugyi_termekado_dohanytermekekre_valo_kiterjesztesenek_lehetosege (megtekintve: 2022. 02. 10.)

[6] Antonio Corral, Jessica Durán and Iñigo Isusi, IKEI Research and Consulting: Employment opportunities for people with chronic diseases, European Foundation for the Improvement of Living and Working Conditions, 2014. https://www.eurofound.europa.eu/sites/default/files/ef 1459en.pdf [megtekintve: 2022. 02. 10]

[7] Joint Statement on "Improving the employment of people with chronic diseases in Europe", Framing paper, 2017. European Chronic Disease Alliance (ECDA) in partnership with stakeholders and Members of the EU Health Policy Platform. https://ec.europa.eu/health/ system/files/201801/2017_chronic_framingdoc_en_0.pdf [megtekintve: 2022. 02. 10]
[8] Chrodis plus - implementing good practices for chronic diseases. http://chrodis.eu/ [megtekintve: 2022. 02. 10]

[9] Dr. Kovács Réka, Aszalós Zoltán, Semmelweis Egyetem, Egészségügyi Közszolgálati Kar, Egészségügyi Menedzserképző Központ: CHRODIS PLUS online konferencia a krónikus betegségekről, Interdiszciplináris Magyar Egészségügy. XIX. Évfolyam, 2020. / 3, augusztus-szeptember, 34. old

https://www.imeonline.hu/article.php?article=2020._XIX. /3/chrodis_plus_online_konferencia_a_kronikus_betegsegekrol [megtekintve: 2022. 02. 10]

[10] Website of CHRODIS PLUS online conference on chronic diseases - 27 October 2020 «Closing the evidencepractice gap on NCDS: translation, transfer and sustainability for comprehensive responses across Europe, http://chrodis.eu/event/chrodis-plus-online-conferenceon-chronic-diseases [megtekintve: 2022. 02. 10]

[11] Chrodis Plus Workbox on Employment and Chronic Conditions. http://chrodis.eu/08-chronic-diseases-andemployment/ [megtekintve: 2022. 02. 10]

[12] Matilde Leonardi, Fabiola Silvaggi, Chiara Scaratti, Erika Guastafierro, Claudia Toppo, Michela Eigenmann, Jaana Lindström, Eeva Rantala, Päivi Valve: A krónikus betegséggel élők munkaképességének és integrációjának fejlesztése a munkahelyeken, Képzési módszertan vezetők számára. http://chrodis.eu/wp-content/uploads/ 2020/10/hun-chrodis-training-tool-2.pdf [megtekintve: 2022. 02. 10]

[13] Eeva Rantala, Jaana Lindström, Päivi Valve, Matilde Leonardi, Fabiola Silvaggi, Chiara Scaratti, Erika Guastafierro, Claudia Toppo, Michela Eigenmann, Karin Proper, Sandra van Oostrom: A munkavállalók egészségének, jóllétének és munkahelyi részvételének elősegítése, Eszköztár munkahelyek számára. http://chrodis. eu/wp-content/uploads/2020/11/chrodis-plus_toolkit_ hu_20201027.pdf [megtekintve: 2022. 02. 10]

[14] UN CONVENTION on the Rights of Persons with Disabilities (CRPD), United Nations, 2006

https://www.un.org/disabilities/documents/convention/co nvoptprot-e.pdf [megtekintve: 2022. 02. 10]

[15] AVAlLONE, F., Farnese, L., Pepe, S., Paplomatas, A. (2007): Il processo di CONVIVENZA. Indagine ESPLORATIVA sulle dimensioni della CONVIVENZA AFFETTIVA, ORGANIZZATIVA, sociale. In AVALLONE, F., Borgogni, L. (a cura di), CONVIVENZA ed efficacia ORGANIZZATIVA, Rassegna di Psicologia, Quaderno speciale 1, Carrocci Editore, Roma, pp. 33

[16] O'Leary, J., Legg, A. (2017), Inclusion@Work Index 2017-2018: Mapping the state of inclusion in the australian workforce. DIVERSITY Council Australia. https://accessandinclusionindex.com.au/ [megtekintve: 2022. 02. 10] 
[17] A munkaképességi index (WAI): http://www.ageingatwork.eu/resources/health-work-in-an-ageing-europeenwhp-3.pdf p34 [megtekintve: 2022. 02. 10]
[18] Morschhäuser M., Sochert R.: Healthy Work in an Ageing Europe - Strategies and Instruments for Prolonging Working Life, ENWHP, 20062

\section{A SZERZŐK BEMUTATÁSA}

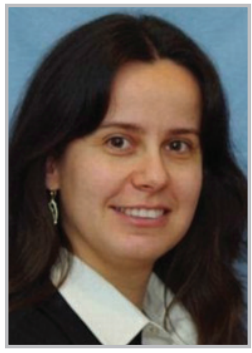

Dr. Kovács Réka 2001-ben a Budapesti Közgazdaságtudományi és Államigazgatási Egyetemen közgazdász, 2003-ban a Pázmány Péter Katolikus Egyetemen jogász végzettséget szerzett, jelenleg az ELTE Jogi Doktori Iskola $\mathrm{PhD}$ hallgatója. Kutatási területe a személyek szabad mozgásának megvalósulását támogató uniós szabályozások, különös tekintettel a határon átnyúló beteg- és szakembermobilitás kérdéseire. 2001-től az Egészségügyi Minisztérium, illetve jogutóda, az Emberi Erőforrások Minisz-

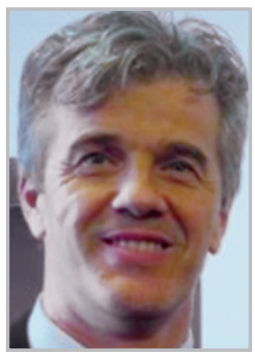

Aszalós Zoltán 1994-ben szerzett közgazdász diplomát a Corvinus Egyetemen. Későbbi diplomái: nemzetközi jog (MPhil-2002), Executive MBA (EMBA 2012), és Adattudomány (MSc-2018). A Semmelweis Egyetem Egészségügyi Menedzserképzőjének munkatársa 2012 óta, ahol projektmenedzser-

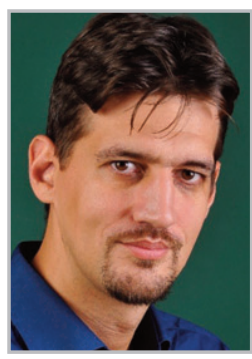

Dr. Cserháti Zoltán általános orvos, háziorvos szakorvos és közgazdász. A Semmelweis Egyetem Magatartástudományi Intézetének munkatársaként, több mint tíz évig vett részt az orvosi kommunikáció oktatásában. Számos hazai kutatásban és nemzetközi projektben vett részt munkahelyi stressz és stresszkezelés, valamint öngyilkosságmegelőzés témakörben (Williams Életkészségek Program, Selye János Lelki Egészség Program, PROMISE, OSPIEurope, PREDI-NU). Alapító munkatársa volt a Semmelweis Egyetem Karrierközpontjának. 2012 és 2015 között az

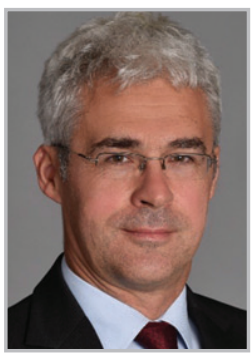

Dr. Palicz Tamás 1993-ban szerezte orvosdoktori diplomáját a Debreceni Egyetemen, majd 1998-ban belgyógyász szakorvos lett. 2003-tól dolgozik vezetőként, kezdetben a Semmelweis Egyetem Stratégiai és Müködésfejlesztési Főigazgatóság főigazgató-helyetteseként, majd 2005-től a Kútvölgyi Klinikai Tömb orvosigazgatójaként szerzett tapasztalatot az egészségügyi szervezetek vezetésében. 2010 és 2013 között a Nemzeti Fejlesztési Ügynökség tériuma európai uniós és nemzetközi szakpolitikai és jogi feladataival foglalkozott szakértőként, osztályvezetőként, végül 2017 decemberétől főosztályvezetőként. 2020 szeptemberétől a Semmelweis Egyetem Egészségügyi Menedzserképző Központ szenior egészségpolitikai és nemzetközi szakértőjeként nemzetközi finanszírozású projektek előkészítésében és végrehajtásában, illetve a nemzetközi kapcsolatrendszer koordinálásában és fejlesztésében vesz részt. A Chrodis Plus projektben a munkahelyi egészségfejlesztéssel foglalkozó munkacsomag munkájához, illetve a projektkommunikációs tevékenységeket támogató szakmai tartalomfejlesztéshez járult hozzá.

ként az EU Egészségügyi Programja, az Európai Innovációs és Technológiai Intézet, valamint a WHO által finanszírozott nemzetközi projektekben munkacsoportok vezetéséért felelős. A krónikus betegségekkel szembeni EU-s szintű fellépést támogató Chrodis Plus projektben a Kommunikációs munkacsoport vezetését látta el, ahol a politikai döntéshozók, az egészségügyi szakemberek, valamint a laikus közönség tájékoztatását is irányította.

Emberi Erőforrások Minisztériumában az Egészségügyi Ágazati Humánerőforrás-stratégiai Főosztályát vezette. 2015-től a Nemzeti Egészségfejlesztési Intézet szakterületi fókuszpontjainak munkáját irányította, majd az Országos Gyógyszerészeti és Élelmezés-egészségügyi Intézet élelmezés- és táplálkozástudományi főigazgató-helyetteseként dolgozott. 2017-2018-ban az Európai Bizottság Táplálkozás és Fizikai Aktivitás Magasszintű Munkacsoportjának, 2018-ban a CHRODIS PLUS projekt irányító tanácsának tagjaként képviselte Magyarországot. 2018. szeptemberétől a Semmelweis Egyetem Egészségügyi Menedzserképző Központjában „Szervezeti magatartás” és „Emberi erőforrás menedzsment” tárgyakat oktat egészségügyi menedzser hallgatók számára.

Humánerőforrás-programok Irányító Hatóságát IHEP IH) irányította. 2015 végétől a Semmelweis Egyetem Egészségügyi Menedzserképző Központ stratégiai igazgató-helyettese. Fő érdeklődési területe az egészségügyi szervezetek folyamatközpontú menedzsmentje, szervezeti változások vezetése és projektmenedzsment. Komoly szakmai tapasztalattal bír az egészségfejlesztés területén is; szakmai vezetője volt az Országos Egészségfejlesztési Intézet és a Klebelsberg Iskolafenntartó Központ konzorciuma által megvalósított teljes körű iskolai egészségfejlesztés bevezetését célzó kiemelt uniós társfinanszírozású projektnek (TÁMOP-612A). 